\title{
PRODUCTION OF HYPERTONIC URINE IN THE ABSENCE OF PITUITARY ANTIDIURETIC HORMONE ${ }^{1}$
}

\author{
BY ROBERT W. BERLINER AND DOUGLAS G. DAVIDSON 2 \\ (From the Laboratory of Kidney and Electrolyte Metabolism, National Heart Institute, National \\ Institutes of Health, Public Health Service, Department of Health, Education, \\ and Welfare, Bethesda, Md.)
}

(Submitted for publication May 1, 1957 ; accepted May 23, 1957)

The mechanism by which pituitary antidiuretic hormone $(\mathrm{ADH})$ produces its renal effect has not been clearly established. Under ordinary conditions, in the absence of $\mathrm{ADH}$, urine of a concentration considerably below that of plasma is produced in large volume. With increasing amounts of $\mathrm{ADH}$, administered or secreted, the osmotic pressure of the urine rises to and above that of plasma. With respect to total water balance, the quantitatively more important contribution to water economy is the change between maximally dilute and isotonic urine, since this, in normal man, may involve a change in water excretion in excess of $10 \mathrm{ml}$. per minute. The further saving of water effected by the elaboration of hypertonic urine is a relatively small one, amounting, at usual rates of solute excretion, to not more than an additional 1 or $2 \mathrm{ml}$. per minute. Thus, although it is commonly stated that the function of $\mathrm{ADH}$ is to cause the excretion of a hypertonic urine, its more important function might be better defined as preventing the excretion of a dilute urine.

Recent studies of the effects of posterior pituitary extracts on frog skin have shown that these preparations markedly reduce the resistance of this membrane to the flow of water in response to gradients of osmotic pressure (1). Observations on frog bladder also suggest this mechanism of action (2). It would seem reasonable to examine the extent to which a similar mechanism of action could explain the effects of $\mathrm{ADH}$ on the concentration of the urine. Since the change from dilute to isotonic urine is clearly in the direction of the dissipation of an osmotic gradient, this effect of $\mathrm{ADH}$ could well be attributed to a change in the

1 The material in this paper was presented in summary form at the meeting of the American Society for Clinical Investigation, Atlantic City, May, 1956.

2 Dr. Davidson's work was done under the tenure of an American Heart Association Fellowship. permeability of the tubule membrane to water. The change to hypertonicity cannot be so readily attributed to an effect on water permeability without some assumptions as to the mechanism by which the hypertonicity is produced. However, it is a reasonable hypothesis that the mechanism for the production of hypertonicity is not dependent upon $\mathrm{ADH}$ but that its effects are unmasked, in the presence of $\mathrm{ADH}$, by 1) changes in the volume and concentration of urine delivered to it and, possibly, 2) changes in the permeability of the membranes separating the concentrating mechanism from the urine in the tubule lumen.

The most tenable view of the mechanism by which the urine is diluted is that the process involves abstraction of solute in a segment of the tubule, presumably the distal convoluted tubule, relatively impermeable to water (3); indeed, the results to be presented strongly support this assumption. The only solute available in quantities adequate to account for the volume of water freed of solute in the process of urine dilution is sodium and its equivalent anions. Anything which limits the amount of sodium salts reaching the diluting segment or the capacity of that segment to remove sodium and anion should reduce the capacity of the kidney to produce a dilute urine. Thus, in the absence of ADH, if one were able to reduce the volume of renal tubule fluid delivered to the diluting segment, it might be possible to limit the amount of water "freed" by the removal of the remaining sodium salts. Under these conditions the volume of fluid and particularly the volume of "free water" leaving the diluting segment and entering the final segment, believed to be the site of the production of hypertonicity, would be small. If the mechanism for rendering a urine hypertonic functions in the absence of $\mathrm{ADH}$, it might be possible, then, to obtain urine hypertonic to plasma since removal of only a small amount of water would be required. 
The experimental investigation of this possibility requires reduction of the rate of glomerular filtration in the absence of antidiuretic hormone. The use of animals or patients with diabetes insipidus is subject to some uncertainty of interpretation since it is not possible ever to exclude with complete certainty some residual capacity to secrete $\mathrm{ADH}$. Indeed, subject to this reservation, a number of observations made in diabetes insipidus have been wholly in accord with the premises set forth above (4-7)..$^{3}$ It appeared probable that the most certain demonstration of the absence of $\mathrm{ADH}$ would be afforded by the presence of a normal kidney continuing to produce a urine of maximum dilution during the necessary manipulations upon the other kidney. This has been the design used in the experiments to be described.

\section{MATERIAL AND METHODS}

Experiments were performed on 12 female mongrel dogs, weighing approximately 20 kilos. The animals were prepared by a bladder-splitting procedure devised by Desautel (9). In this operation the bladder is separated from the urethra and divided longitudinally into two halves, each containing one ureteral orifice. Each half is then formed into a pouch and connected to the outside through a nylon funnel protruding through the skin of the abdomen through separate wounds. Urine from each kidney thus drains separately and continuously to the outside. The length of the nylon tube protruding through the abdominal wall was sufficient to prevent drainage directly onto the skin and to permit the connection of a short length of rubber catheter during urine collections. Between experiments the dogs were kept in metabolism cages so that the continuous drainage of urine left them relatively dry.

At the same time as the bladder-splitting operation, the right renal artery was approached through a separate incision in the flank. The artery was freed and any branches other than those to the kidney were ligated and severed. A small inflatable cuff of silicone rubber (silastic, Dow Corning) enclosed in a tantalum clip (Figure 1) was placed around the right renal artery and, in order to prevent extrusion of the artery upon inflation of the cuff, the ends of the tantalum clip were brought together with a loop of stainless steel wire. The silicone rubber cuff was then connected permanently to the exterior of the animal by a length of polyethylene tubing

\footnotetext{
${ }^{3}$ In addition, since completion of these studies del Greco and de Wardener (8) have reported the production of hypertonic urine upon reduction of glomerular filtration rate under conditions in which the action of ADH was believed to be excluded.
}

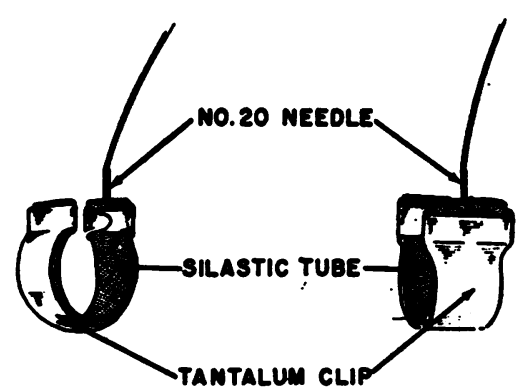

Fig. 1. Inflatable Cuff Used for Compression of the Right Renal Artery

(O.D., $1.27 \mathrm{~mm}$.) brought out through a separate stab wound in the flank.

Either before or after the surgical procedure the dogs were trained to stand quietly, partially supported by a sling under the chest and around each hind quarter. They were also trained to accept a stomach tube and venipuncture without interruption of a water diuresis. All experiments were performed on such trained animals without anesthesia.

Water diuresis was induced by the administration by stomach tube of approximately $30 \mathrm{ml}$. of water per kilo of body weight. The water load was then maintained by the continuous intravenous administration of an infusion at a rate estimated to approximate the expected urine flow and containing in addition to creatinine and/or inulin, $p$-aminohippurate $(\mathrm{PAH})$ in amounts expected to insure complete extraction, mannitol at a concentration of 1 to 2 per cent in many of the experiments, small amounts of $\mathrm{NaCl}$ to replace anticipated losses in most of the studies, and sufficient glucose or fructose to bring the concentration of the solution to a non-hemolytic level.

Equality of renal function on the two sides was established by the collection of urine from each kidney during several periods before inflation of the renal artery cuff. In satisfactory surgical preparations, the filtration rates of the two kidneys were within 10 per cent of each other and in most instances within 5 per cent. The urine flow and concentration and the rates of excretion of sodium, potassium and chloride from the two kidneys were also very close to equal.

After collection of the control periods, the polyethylene tube communicating with the cuff was connected to a mercury manometer and the cuff inflated with air until the urine flow from the right kidney had been reduced to the desired level. This frequently required repeated adjustment of the pressure level since there was almost uniformly a greater depression of the urine flow during the first few minutes of compression than was apparent subsequently (10). When the desired level of urine flow had been obtained and maintained long enough to indicate

* We are greatly indebted to Dr. Robert L. Bowman for devising and constructing the inflatable cuff, and to Drs. Jerome Kay and Edward Sharp for performing the surgical procedures. 
TABLE I

Dog $L, 3-29-56$

\begin{tabular}{|c|c|c|c|c|c|c|c|c|c|c|c|c|c|}
\hline \multirow[b]{2}{*}{ Time } & \multicolumn{2}{|c|}{$\begin{array}{l}\text { Urine } \\
\text { flow }\end{array}$} & \multicolumn{2}{|c|}{$\begin{array}{c}\text { PAH } \\
\text { clearance }\end{array}$} & \multicolumn{2}{|c|}{$\begin{array}{c}\text { Inulin } \\
\text { clearance }\end{array}$} & \multicolumn{2}{|c|}{$\begin{array}{c}\text { Urine } \\
\text { osmolality }\end{array}$} & \multicolumn{2}{|c|}{$\begin{array}{c}\text { Solute } \\
\text { excretion }\end{array}$} & \multirow{2}{*}{$\begin{array}{c}\text { Plasma } \\
\text { osmolality }\end{array}$} & \multicolumn{2}{|c|}{$\begin{array}{l}\text { Chloride } \\
\text { excretion }\end{array}$} \\
\hline & R. & L. & $\mathbf{R}$. & L. & R. & L. & $\mathbf{R}$. & L. & $\mathbf{R}$. & L. & & R. & $\bar{L}$. \\
\hline $\min$. & \multicolumn{2}{|c|}{$\operatorname{ml} . / \min$. } & \multicolumn{2}{|c|}{$m l . / m i x}$. & \multicolumn{2}{|c|}{ ml./min. } & \multicolumn{2}{|c|}{$\underset{H_{2} \mathrm{O}}{\operatorname{mosm}_{.} / \mathrm{Kg}_{\mathrm{g}}}$} & \multicolumn{2}{|c|}{ MOsm./min. } & $\underset{H_{2} \mathrm{O}}{m O_{s m} / K_{g}}$ & \multicolumn{2}{|c|}{$\mu E q . / \min }$. \\
\hline $\begin{array}{l}-57 \\
-54\end{array}$ & \multicolumn{13}{|c|}{$\begin{array}{l}600 \mathrm{ml} . \mathrm{H}_{2} \mathrm{O} \text { by stomach tube. } \\
\text { Priming inulin injection } 400 \mathrm{mg} \text {. Start infusions a) inulin } 1.5 \mathrm{mg} . / \mathrm{ml} \text {., mannitol } 60 \mu \mathrm{M} / \mathrm{ml} \text {, } \\
\text { glucose } 100 \mu \mathrm{M} / \mathrm{ml} \text {., } \mathrm{NaCl} 10 \mu \mathrm{M} / \mathrm{ml} \text {. in } \mathrm{H}_{2} \mathrm{O} \text { at } 6.7 \mathrm{ml} . / \mathrm{min} \text {.; and b) } \mathrm{PAH} 5 \mathrm{mg} . / \mathrm{ml} \text {. in } 0.4 \% \\
\mathrm{NaCl} \text { solution at } 1 \mathrm{ml} . / \mathrm{min} \text {. }\end{array}$} \\
\hline $\begin{array}{c}0-7 \\
8-15 \\
16-23 \\
24-30\end{array}$ & $\begin{array}{l}3.2 \\
3.9 \\
3.6 \\
3.8\end{array}$ & $\begin{array}{l}3.1 \\
3.4 \\
3.1 \\
3.2\end{array}$ & $\begin{array}{l}243 \\
251 \\
236 \\
257\end{array}$ & $\begin{array}{l}246 \\
259 \\
228 \\
248\end{array}$ & $\begin{array}{l}45 \\
44 \\
41 \\
44\end{array}$ & $\begin{array}{l}42 \\
42 \\
38 \\
42\end{array}$ & $\begin{array}{l}96 \\
93 \\
89 \\
85\end{array}$ & $\begin{array}{r}113 \\
99 \\
95 \\
96\end{array}$ & $\begin{array}{l}308 \\
358 \\
318 \\
326\end{array}$ & $\begin{array}{l}346 \\
339 \\
292 \\
304\end{array}$ & $\begin{array}{l}280 \\
278\end{array}$ & $\begin{array}{r}9 \\
13 \\
15 \\
14\end{array}$ & $\begin{array}{l}12 \\
12 \\
15 \\
12\end{array}$ \\
\hline 32 & \multicolumn{13}{|c|}{$\begin{array}{l}\text { Cuff on right renal artery inflated. } \\
\text { Mannitol in infusion a) replaced with equivalent amount of glucose. }\end{array}$} \\
\hline $\begin{array}{l}114-122 \\
124-130\end{array}$ & $\begin{array}{l}1.3 \\
1.7\end{array}$ & $\begin{array}{l}2.9 \\
2.8\end{array}$ & $\begin{array}{l}118 \\
120\end{array}$ & $\begin{array}{l}131 \\
133\end{array}$ & $\begin{array}{l}34 \\
37\end{array}$ & $\begin{array}{l}39 \\
43\end{array}$ & $\begin{array}{l}153 \\
128\end{array}$ & $\begin{array}{l}83 \\
89\end{array}$ & $\begin{array}{l}204 \\
216\end{array}$ & $\begin{array}{l}244 \\
245\end{array}$ & $\begin{array}{l}272 \\
265\end{array}$ & $\begin{array}{l}3 \\
4\end{array}$ & $\begin{array}{l}7 \\
6\end{array}$ \\
\hline 132 & \multicolumn{13}{|c|}{ Cuff pressure readjusted. } \\
\hline $\begin{array}{l}181-208 \\
210-240 \\
241-270 \\
271-301 \\
302-327\end{array}$ & $\begin{array}{l}0.07 \\
0.09 \\
0.11 \\
0.11 \\
0.13\end{array}$ & $\begin{array}{l}2.4 \\
2.7 \\
2.8 \\
3.0 \\
2.8\end{array}$ & $\begin{array}{l}45 \\
49 \\
70 \\
81 \\
85\end{array}$ & $\begin{array}{l}107 \\
112 \\
110 \\
120 \\
120\end{array}$ & $\begin{array}{l}12 \\
15 \\
23 \\
24 \\
25\end{array}$ & $\begin{array}{l}40 \\
42 \\
44 \\
42 \\
44\end{array}$ & $\begin{array}{l}388 \\
358 \\
333 \\
325 \\
292\end{array}$ & $\begin{array}{l}83 \\
74 \\
68 \\
64 \\
69\end{array}$ & $\begin{array}{l}25 \\
31 \\
38 \\
36 \\
37\end{array}$ & $\begin{array}{l}199 \\
198 \\
190 \\
184 \\
191\end{array}$ & $\begin{array}{l}267 \\
263 \\
257 \\
257 \\
257\end{array}$ & $\begin{array}{l}1 \\
1 \\
1 \\
1 \\
1.5\end{array}$ & $\begin{array}{l}7 \\
8 \\
7 \\
8 \\
7\end{array}$ \\
\hline
\end{tabular}

stability, sufficient time was allowed, before collection of urine, to minimize dead space errors due to changes in urine flow and concentration. (During these manipulations, urine flow from the control kidney remained unaffected.) After collection of several periods at a given level of pressure, the pressure was generally adjusted to another level and several additional periods collected. In other experiments, as indicated in the results, the content of the infusion was changed or vasopressin was administered by continuous infusion in a solution brought to $\mathrm{pH} 5.2$ to 5.5 with acetic acid. In a few experiments, observations were made after deflation of the cuff; in these there was a prompt return of urine flow and concentration to control levels. Midpoint blood samples were

TABLE II

Dog $S, 8-5-55$

\begin{tabular}{|c|c|c|c|c|c|c|c|c|c|c|c|c|c|}
\hline \multirow[b]{2}{*}{ Time } & \multicolumn{2}{|c|}{$\begin{array}{l}\text { Urine } \\
\text { flow }\end{array}$} & \multicolumn{2}{|c|}{$\begin{array}{c}\text { PAH } \\
\text { clearance }\end{array}$} & \multicolumn{2}{|c|}{$\begin{array}{l}\text { Creatinine } \\
\text { clearance }\end{array}$} & \multicolumn{2}{|c|}{$\begin{array}{c}\text { Urine } \\
\text { osmolality }\end{array}$} & \multicolumn{2}{|c|}{$\begin{array}{c}\text { Solute } \\
\text { excretion }\end{array}$} & \multirow{2}{*}{$\begin{array}{c}\text { Plasma } \\
\text { osmolality }\end{array}$} & \multicolumn{2}{|c|}{$\begin{array}{l}\text { Chloride } \\
\text { excretion }\end{array}$} \\
\hline & $\mathbf{R}$. & L. & R. & L. & R. & L. & $\mathbf{R}$. & L. & R. & L. & & R. & L. \\
\hline $\min$. & \multicolumn{2}{|c|}{ ml./min. } & \multicolumn{2}{|c|}{$\operatorname{ml.} / \min }$. & \multicolumn{2}{|c|}{ ml./min. } & \multicolumn{2}{|c|}{$\underset{H_{2} \mathrm{O}}{\operatorname{mosm}_{.} / K_{8}}$} & \multicolumn{2}{|c|}{$\mu O s m . / \min }$. & $\underset{H_{5} \mathrm{O}}{\operatorname{mOsm} . / K_{\mathrm{g}}}$ & \multicolumn{2}{|c|}{$\mu E q . / \min }$. \\
\hline $\begin{array}{l}-91 \\
-62\end{array}$ & \multicolumn{13}{|c|}{$\begin{array}{l}500 \mathrm{ml} . \mathrm{H}_{2} \mathrm{O} \text { by stomach tube. } \\
\text { Priming injection creatinine } 2 \mathrm{Gm} \text {., PAH } 20 \mathrm{mg} \text {. Start inf } \\
\text { PAH } 0.15 \mathrm{mg} . / \mathrm{ml} \text {., } \mathrm{NaCl} 20 \mu \mathrm{M} / \mathrm{ml} \text {., mannitol } 120 \mu \mathrm{M} / \mathrm{m}\end{array}$} \\
\hline $\begin{array}{r}0-11 \\
12-22\end{array}$ & $\begin{array}{l}5.2 \\
5.5\end{array}$ & $\begin{array}{l}5.0 \\
5.7\end{array}$ & $\begin{array}{l}145 \\
138\end{array}$ & $\begin{array}{l}153 \\
157\end{array}$ & $\begin{array}{l}39 \\
37\end{array}$ & $\begin{array}{l}40 \\
39\end{array}$ & $\begin{array}{l}108 \\
100\end{array}$ & $\begin{array}{l}110 \\
103\end{array}$ & $\begin{array}{l}566 \\
550\end{array}$ & $\begin{array}{l}550 \\
588\end{array}$ & 282 & $\begin{array}{l}6.1 \\
8.7\end{array}$ & $\begin{array}{l}5.9 \\
5.7\end{array}$ \\
\hline 24 & \multicolumn{13}{|c|}{ Cuff on right renal artery inflated. } \\
\hline $\begin{array}{l}44-57 \\
58-71\end{array}$ & $\begin{array}{l}0.54 \\
0.54\end{array}$ & $\begin{array}{l}7.3 \\
7.8\end{array}$ & $\begin{array}{l}21 \\
77\end{array}$ & $\begin{array}{l}164 \\
165\end{array}$ & $\begin{array}{l}8 \\
8\end{array}$ & $\begin{array}{l}38 \\
40\end{array}$ & $\begin{array}{l}218 \\
240\end{array}$ & $\begin{array}{l}103 \\
109\end{array}$ & $\begin{array}{l}118 \\
131\end{array}$ & $\begin{array}{l}755 \\
850\end{array}$ & $\begin{array}{l}280 \\
276\end{array}$ & $\begin{array}{l}0.3 \\
0.6\end{array}$ & $\begin{array}{l}40 \\
48\end{array}$ \\
\hline 72 & \multicolumn{13}{|c|}{ Pressure in cuff readjusted. } \\
\hline $\begin{array}{l}82-90 \\
91-98\end{array}$ & $\begin{array}{l}2.3 \\
2.6\end{array}$ & $\begin{array}{l}8.8 \\
8.8\end{array}$ & $\begin{array}{l}112 \\
181\end{array}$ & $\begin{array}{l}188 \\
181\end{array}$ & $\begin{array}{l}18 \\
22\end{array}$ & $\begin{array}{l}41 \\
39\end{array}$ & $\begin{array}{l}150 \\
168\end{array}$ & $\begin{array}{l}114 \\
115\end{array}$ & $\begin{array}{l}348 \\
442\end{array}$ & $\begin{array}{r}997 \\
1,006\end{array}$ & $\begin{array}{l}278 \\
276\end{array}$ & $\begin{array}{l}6 \\
6\end{array}$ & $\begin{array}{l}69 \\
65\end{array}$ \\
\hline 99 & \multicolumn{13}{|c|}{ Cuff deflated. } \\
\hline $\begin{array}{l}107-112 \\
143-147\end{array}$ & $\begin{array}{l}6.1 \\
5.9\end{array}$ & $\begin{array}{l}7.5 \\
6.3\end{array}$ & $\begin{array}{l}146 \\
102\end{array}$ & $\begin{array}{l}134 \\
103\end{array}$ & $\begin{array}{l}33 \\
31\end{array}$ & $\begin{array}{l}35 \\
32\end{array}$ & $\begin{array}{l}117 \\
124\end{array}$ & $\begin{array}{l}118 \\
122\end{array}$ & $\begin{array}{l}714 \\
728\end{array}$ & $\begin{array}{l}878 \\
774\end{array}$ & $\begin{array}{l}276 \\
282\end{array}$ & 14 & $\begin{array}{l}32 \\
13\end{array}$ \\
\hline
\end{tabular}


TABLE III

$\operatorname{Dog} M, 1-16-56$

\begin{tabular}{|c|c|c|c|c|c|c|c|c|c|c|c|}
\hline \multirow[b]{2}{*}{ Time } & \multicolumn{2}{|c|}{$\begin{array}{l}\text { Urine } \\
\text { flow }\end{array}$} & \multicolumn{2}{|c|}{$\begin{array}{c}\text { PAH } \\
\text { clearance }\end{array}$} & \multicolumn{2}{|c|}{$\begin{array}{c}\text { Inulin } \\
\text { clearance }\end{array}$} & \multicolumn{2}{|c|}{$\begin{array}{c}\text { Urine } \\
\text { osmolality }\end{array}$} & \multicolumn{2}{|c|}{$\begin{array}{c}\text { Solute } \\
\text { excretion }\end{array}$} & \multirow{2}{*}{$\begin{array}{c}\text { Plasma } \\
\text { osmolality }\end{array}$} \\
\hline & R. & L. & R. & L. & $\mathbf{R}$. & $\overline{\mathbf{L} .}$ & R. & $\overline{\mathbf{L} .}$ & R. & $\overline{\mathbf{L} .}$ & \\
\hline $\min$. & \multicolumn{2}{|c|}{$\operatorname{ml} . / \min }$. & \multicolumn{2}{|c|}{$m l . / m i n}$. & \multicolumn{2}{|c|}{$\operatorname{ml} . / \min }$. & \multicolumn{2}{|c|}{ 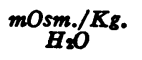 } & \multicolumn{2}{|c|}{ ${ }_{0}$ sm./min. } & 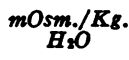 \\
\hline $\begin{array}{l}-69 \\
-64\end{array}$ & \multicolumn{10}{|c|}{$\begin{array}{l}750 \mathrm{ml} . \mathrm{H}_{2} \mathrm{O} \text { by stomach tube. } \\
\mathrm{Start} \text { infusion: creatinine } 2 \mathrm{mg} . / \mathrm{ml} \text {., inulin } 2 \mathrm{mg} . / \mathrm{ml} ., \text { PAH } 0.7 \mathrm{mg} . / \mathrm{ml} \text {., } \\
\mathrm{NaCl} 10 \mu \mathrm{M} / \mathrm{ml} . \text {, mannitol approx. } 100 \mu \mathrm{M} / \mathrm{ml} \text {., glucose approx. } 85 \mu \mathrm{M} / \mathrm{ml} \text {. } \\
\text { at } 6.9 \mathrm{ml} . / \mathrm{min} \text {. }\end{array}$} & \\
\hline $\begin{array}{c}0-7 \\
8-15 \\
16-23\end{array}$ & $\begin{array}{l}4.7 \\
5.1 \\
4.8\end{array}$ & $\begin{array}{l}4.6 \\
5.2 \\
4.9\end{array}$ & $\begin{array}{l}177 \\
195 \\
176\end{array}$ & $\begin{array}{l}200 \\
208 \\
192\end{array}$ & $\begin{array}{l}45 \\
46 \\
43\end{array}$ & $\begin{array}{l}44 \\
47 \\
45\end{array}$ & $\begin{array}{l}98 \\
98 \\
98\end{array}$ & $\begin{array}{l}107 \\
102 \\
106\end{array}$ & $\begin{array}{l}460 \\
504 \\
470\end{array}$ & $\begin{array}{l}502 \\
531 \\
515\end{array}$ & 283 \\
\hline 25 & \multicolumn{11}{|c|}{$\begin{array}{l}\text { Replace mannitol in infusion with equivalent amount of glucose. } \\
\text { Inflate cuff on right renal artery. }\end{array}$} \\
\hline $\begin{array}{l}56-62 \\
65-72 \\
76-83 \\
83-88\end{array}$ & $\begin{array}{l}1.5 \\
1.1 \\
0.96 \\
1.6\end{array}$ & $\begin{array}{l}4.9 \\
4.8 \\
4.4 \\
4.2\end{array}$ & $\begin{array}{l}164 \\
145 \\
118 \\
114\end{array}$ & $\begin{array}{l}164 \\
160 \\
150 \\
147\end{array}$ & $\begin{array}{l}38 \\
33 \\
30 \\
31\end{array}$ & $\begin{array}{l}47 \\
47 \\
45 \\
48\end{array}$ & $\begin{array}{l}212 \\
235 \\
240 \\
162\end{array}$ & $\begin{array}{r}106 \\
102 \\
96 \\
98\end{array}$ & $\begin{array}{l}326 \\
258 \\
230 \\
252\end{array}$ & $\begin{array}{l}523 \\
492 \\
420 \\
412\end{array}$ & $\begin{array}{l}280 \\
279 \\
277 \\
277\end{array}$ \\
\hline 89 & \multicolumn{11}{|c|}{ Cuff pressure readjusted. } \\
\hline $\begin{array}{l}102-110 \\
120-132 \\
138-148 \\
151-162\end{array}$ & $\begin{array}{l}0.85 \\
0.66 \\
0.58 \\
0.54\end{array}$ & $\begin{array}{l}4.0 \\
4.0 \\
4.0 \\
4.0\end{array}$ & $\begin{array}{r}115 \\
112 \\
95 \\
86\end{array}$ & $\begin{array}{l}152 \\
130 \\
115 \\
112\end{array}$ & $\begin{array}{l}33 \\
33 \\
31 \\
27\end{array}$ & $\begin{array}{l}48 \\
47 \\
46 \\
46\end{array}$ & $\begin{array}{l}251 \\
285 \\
302 \\
271\end{array}$ & $\begin{array}{l}98 \\
93 \\
87 \\
81\end{array}$ & $\begin{array}{l}214 \\
189 \\
175 \\
145\end{array}$ & $\begin{array}{l}388 \\
369 \\
348 \\
324\end{array}$ & $\begin{array}{l}276 \\
275 \\
274 \\
273\end{array}$ \\
\hline
\end{tabular}

collected from an indwelling venous needle in all periods.

Inulin was determined by the procedure of Walser, Davidson, and Orloff (11), creatinine by that of Kennedy, Hilton, and Berliner (12), p-aminohippurate (PAH) by the method of Bratton and Marshall (13), sodium and potassium by internal standard flame photometry, and chloride by electrometric titration. Urine and plasma osmolality was determined by the freezing point method using the apparatus described by Bowman, Trantham, and Caulfield (14).

\section{RESULTS}

Experiments involving inflation of the renal artery cuff during maximum water diuresis were performed in 12 dogs. The results were qualitatively the same in all. Every measurable depression of the rate of glomerular filtration was accompanied by a rise in the concentration of the urine from the experimental kidney. At some time in each of these dogs urine hypertonic to the plasma was obtained from the experimental kidney when the urine from the control kidney was indicative of maximum water diuresis. Illustrative experiments are represented in Tables I to III and the massed data from four of the dogs are plotted in Figures 2 to 5 . In the figures, the ratio of urine osmolalities, experimental kidney to control kidney, is plotted against the corresponding ratio of glomeru- lar filtration rates. ${ }^{5}$ Points grouped about the ratio of 1.0 for both variables represent control periods before inflation of the cuff and indicate that there was no consistent difference between the two kidneys with respect to either rate of glomerular filtration or urine osmolality.

The data presented in Table I illustrate the

5 In Dog S, only creatinine clearances were measured; in the other three dogs presented here, as well as in experiments upon two additional dogs, both creatinine and inulin clearances were measured. During control periods before application of pressure to the right renal artery the clearance of creatinine averaged 90 per cent of the inulin clearance for both kidneys. During inflation of the cuff the creatinine-inulin clearance ratio averaged 0.89 for the left (control) and 0.88 for the right (experimental) kidney. These creatinine-inulin clearance ratios are slightly lower than has been found previously (12), but, except for two aberrant periods (among approximately 100 ) yielding ratios of 0.58 and 0.61 , there was no tendency for the clearances to diverge during the experimental manipulations. It is therefore concluded that changes in the clearance of either substance reflected similar changes in the rate of glomerular filtration. These results differ from those reported by Ladd, Liddle, and Gagnon (15), who found that the creatinine-inulin clearance ratio fell when one renal artery was clamped. However, the experimental conditions also differed in that the latters' experiments were done with hydropenic animals under anesthesia and subjected to surgical manipulations. 
production of a rather marked degree of urinary concentration and maintenance of the concentration of the urine above that of plasma for a relatively prolonged period. In this experiment, the infusion of mannitol was discontinued at the time of inflation of the cuff and the rate of solute excretion was quite low during the period in which hypertonic urine was formed. At the time that the urine of highest osmolality was obtained the inulin clearance of the experimental kidney was some 70 per cent lower than that of the control kidney. The urine remained hypertonic to plasma over a period of two and a half hours, although the inulin clearance rose to approximately 55 per cent of control values.

Although urines of osmolality greater than 300 mOsm. per $\mathrm{Kg} \cdot \mathrm{H}_{2} \mathrm{O}$ were regularly observed in these experiments, it was unusual to obtain urines with concentrations in excess of $350 \mathrm{mOsm}$. per $\mathrm{Kg} . \mathrm{H}_{2} \mathrm{O}$ and concentrations over $400 \mathrm{mOsm}$. per $\mathrm{Kg} . \mathrm{H}_{2} \mathrm{O}$ (up to 465 ) were observed in only two experiments in which the concentration of urine from the control kidney made it possible to exclude spontaneous secretion of antidiuretic hormone. Unfortunately, neither dog represented a satisfactory experimental preparation since one had chronic constriction of the right renal artery by the mechanical clamp used in some of the earliest experiments while the right kidney of the other dog functioned during control periods at about two-thirds the level of the normal kidney. The difference was subsequently shown at autopsy to be due to an infarct involving approximately one-third of the kidney. It is of interest that in this dog, although all the excretion rates were reduced by approximately one-third, the concentration of all the measured urinary constituents and the total osmolality were virtually identical to those of the normal kidney.

In the massed data it is apparent that there is marked variability 1 ) in the extent of the increase in osmolality obtained with a given reduction in glomerular filtration rate, and 2) in the extent of the reduction in glomerular filtration rate required to produce hypertonicity of the urine. Aside from a relatively small contribution of unavoidable dead space errors, ${ }^{6}$ this variability is attributable largely

${ }^{6} \mathrm{~A}$ rise in the rate of urine formation during a collection period will make the urine appear more concentrated than that actually being formed and give a falsely high value for the inulin clearance. Decreases in urine flow have the opposite effect.

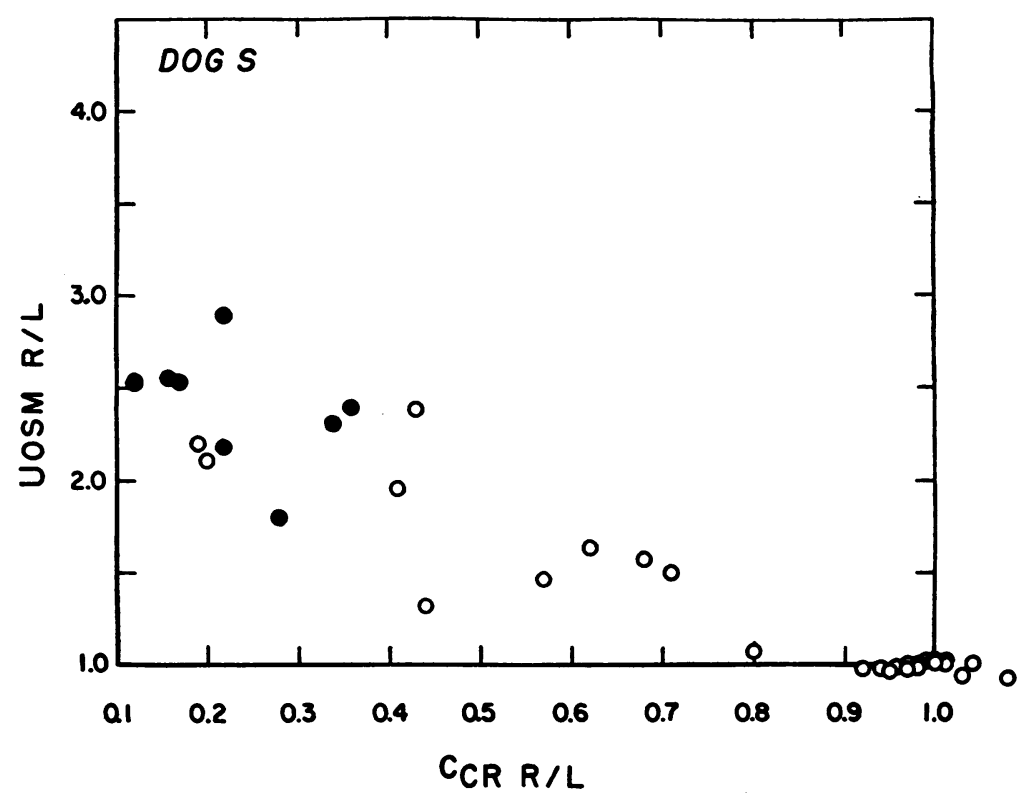

Fig. 2. Ratio of Urine Osmolalities (Experimental to Control Kidney) Plotted Against Corresponding Ratio of Exogenous Creatinine Clearances

Filled circles indicate that the urine from the experimental kidney was hypertonic to plasma. 


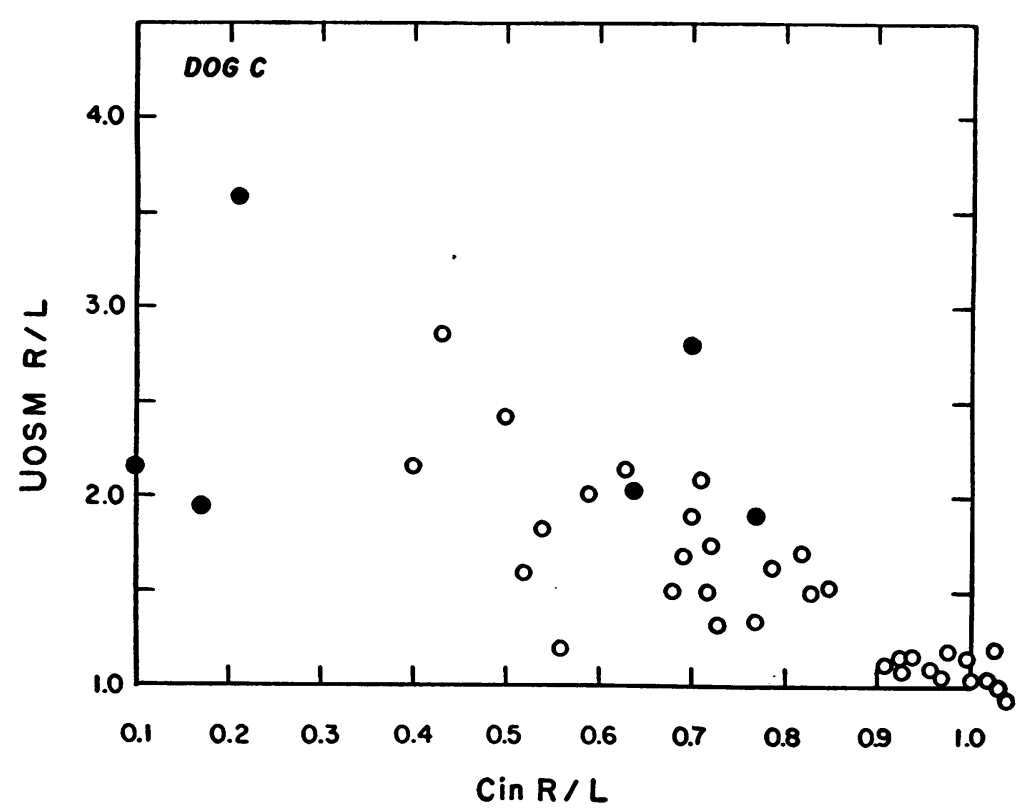

FIG. 3.

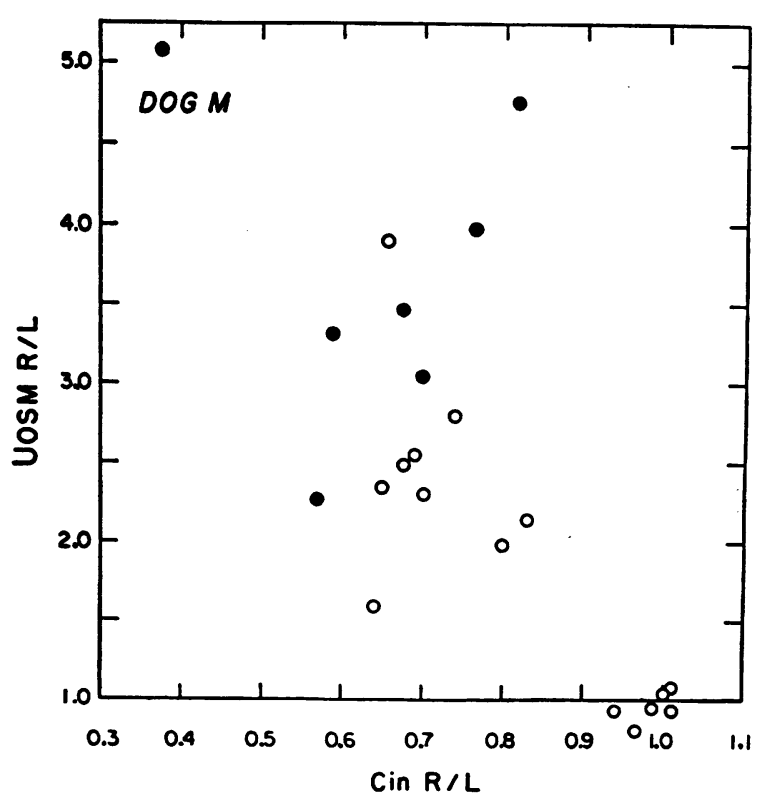

FIG. 4.

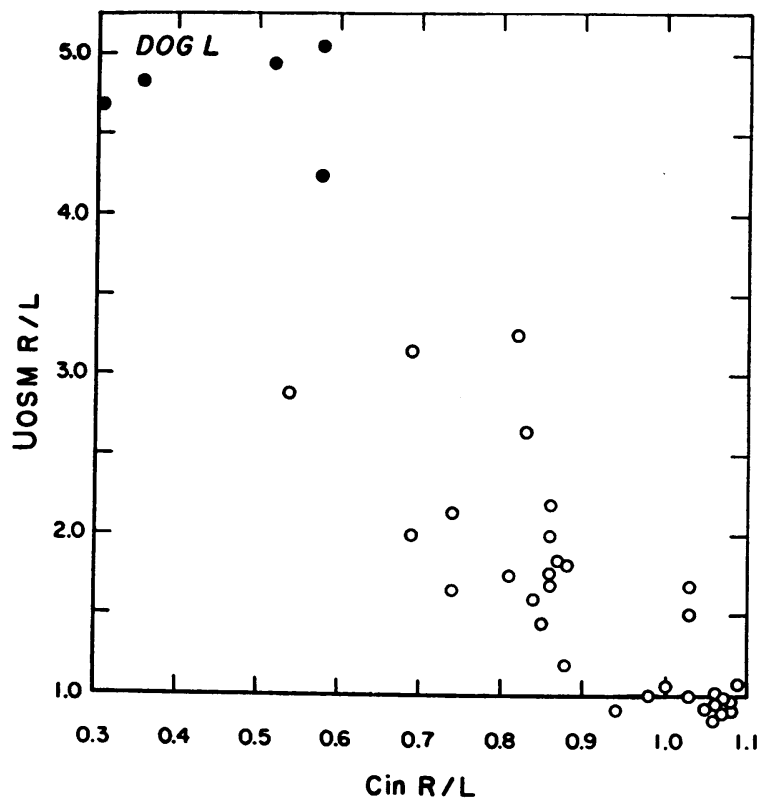

FIG. 5 .

Figs. 3-5. Ratio of Urine Osmolalities (Experimental to Control Kidney) Plotted Against Corresponding Ratio of Inulin Clearances

Filled circles indicate that the urine from the experimental kidney was hypertonic to plasma.

to variation in the rate of solute excretion; dif- fect of solute excretion is exerted in two ways : 1) ferences in solute output among different experiments and among experimental periods in the same experiment resulted in large measure from the rate at which mannitol was administered. The efAt high rates of solute excretion the urine from the control kidney, although containing large amounts of "free water," is less dilute than when the rate of solute excretion is lower; a given urine concen- 
tration on the experimental side therefore yields a lower ratio when solute excretion is high on the control side; and 2) the extent of reduction of glomerular filtration required to attain a certain absolute level of osmolality increases with the rate of solute excretion. Large amounts of mannitol were administered in all of the experiments in Dog S (Figure 2) and in nearly all the periods in Dog C (Figure 3). The effects of the rate of solute excretion are shown in greater detail in the experiments in Tables II and III. Mannitol was infused at a rate of approximately $1,400 \mu \mathrm{M}$ per minute throughout the experiment detailed in Table II. Although large amounts of "free water" ( 3.6 to $5.1 \mathrm{ml}$.) were excreted by the control left kidney, the osmolality of the urine remained in excess of $100 \mathrm{mOsm}$. per $\mathrm{Kg} . \mathrm{H}_{2} \mathrm{O}$. Despite the marked depression of glomerular filtration rate (up to 80 per cent), only a moderate rise in the concentration of the urine from the experimental kidney was produced. In this experiment, the prompt restoration of equality of the two kidneys with respect to all of the measured variables upon release of the renal artery compression is indicated.

In the experiment shown in Table III, mannitol was omitted from the infusion at the time the cuff was inflated on the right renal artery. During the

\section{EFFECT OF INFUSED ADH ON URINE CONCENTRATION} DURING RENAL ARTERY CLAMPING

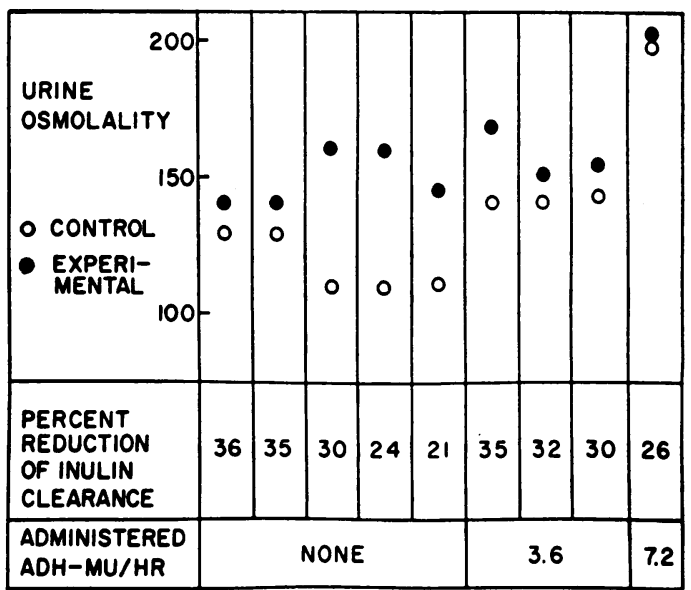

Fig. 6. Osmolality of Urine From Control (Open Circles) and Experimental (Filled Circles) Kmoneys During Infusion of Vasopressin at Indicated Rates

Extent of reduction of inulin clearance by the experimental kidney is indicated for each period. remainder of the experiment there was therefore a gradually diminishing rate of solute excretion. This was accompanied by a fall in the concentration of the urine on the control side and a rise in that obtained from the experimental kidney, although the inulin clearance of each kidney remained fairly stable.

In order to exclude definitively any role of antidiuretic hormone in the changes in urine concentration observed when the rate of glomerular filtration was depressed, it seemed desirable to exclude the possibility of sensitization of the experimental kidney to minimal amounts of circulating hormone which might be insufficient to affect the control kidney. A number of experiments were therefore performed in which exogenous antidiuretic hormone (Pitressin ${ }^{\circledR}$, Parke, Davis and Company) was infused. In these experiments it was found that 1) amounts of antidiuretic hormone which produced no effect on the control kidney had no detectable effect on the kidney with constricted renal artery and 2) when an antidiuretic effect was produced the changes in urine flow and concentration from the experimental kidney were never greater than those on the control side; in fact, the usual consequence was a diminution of the discrepancy in the concentrations of the urine from the two kidneys. An example is shown in Figure 6. In this experiment, mannitol was infused throughout in order to maintain a urine flow which would make possible relatively short urine collection periods. A series of observations were made during moderate reductions of the filtration rate without administration of exogenous $\mathrm{ADH}$. (The relatively high concentration of the urine from the control kidney during the two periods shown at the left of the figure suggests secretion of endogenous $\mathrm{ADH}$.) After these control observations, exogenous $\mathrm{ADH}$ was administered at a rate of $3.6 \mathrm{mU}$ per hour $(0.2 \mathrm{mU}$ per $\mathrm{Kg}$. per hour), and after allowing time for achievement of a steady state, several additional periods were collected. The infusion rate was then doubled and the procedure repeated. In the latter group of periods only one was obtained in which the reduction of inulin clearance was comparable to that of the control periods. It may be seen that, although the concentration of the urine from the experimental kidney increased when Pitressin was administered, the increment of osmolality was smaller, 
both absolutely and relatively, than the change in concentration of the urine from the control kidney and that the difference in osmolality was sharply diminished.

The rates of excretion of chloride are indicated in Tables I and II. ${ }^{7}$ The data included are typical of the findings in these experiments. The rates of excretion of chloride and of sodium by both kidneys were low except when large amounts of mannitol were excreted. The sodium excretion was always lower than that of chloride. The excretion of sodium and chloride by the experimental kidney was depressed, when the cuff was inflated, to an extent far greater, relatively, than the decrease in glomerular filtration rate. The percentage reduction of sodium excretion was almost always greater than that of chloride excretion. Despite the rises in total solute concentration when the cuff was inflated, sodium and chloride concentrations were almost always lower in the urine from the experimental than from the control kidneys.

The rate of excretion of potassium (usually 10 to $20 \mu \mathrm{Eq}$. per minute per kidney) was generally somewhat higher than that of sodium or chloride and was depressed, by inflation of the cuff, to a much smaller extent. With moderate decreases in inulin clearance the depression of potassium excretion was relatively smaller than the decrease in glomerular filtration rate and was frequently negligible. With more marked decreases in the rate of glomerular filtration there was a rapid falling off of potassium excretion which was then proportionately greater than the depression of glomerular filtration rate.

In each experiment presented in full (Tables I to III) the PAH clearances of the control kidneys fell progressively through the experiment. This decrease, although somewhat variable in extent, was a uniform finding in all of the experiments. Its significance is not clear. It seems unlikely that it represented an actual fall in renal plasma flow since decreases, often in excess of 50 per cent, were associated with no other systematic changes in the function of the control kidney which maintained a relatively constant rate of glomerular fil-

\footnotetext{
7 In the experiment in Table III, chloride excretion by the control kidney did not exceed $2 \mu \mathrm{Eq}$. per minute, and sodium excretion barely exceeded $1 \mu \mathrm{Eq}$. per minute. The data have therefore been omitted.
}

tration and, within the limitations imposed by the changes in mannitol administration, constant rates of excretion of sodium, potassium, chloride and water. It is more probable that the gradual fall in PAH clearance was due to fall in PAH extraction, although no reason for such a fall is apparent. ${ }^{8}$

This phenomenon has not been investigated further since it has not been possible, with the PAH currently in use, to reproduce the fall in $\mathrm{PAH}$ clearance observed in the studies reported here. However, more recent experiments using the same manipulative technique confirm the observation of the experiments described in this paper that the reduction in inulin clearance, when the cuff is inflated, is always proportionately greater than the reduction in PAH clearance. It seems most likely that the administered PAH was contaminated with some material giving the same color reaction but having a much lower clearance and hence accumulating in the plasma in the course of the experiment. We believe that the ratio of $\mathrm{PAH}$ clearances is a reasonably accurate reflection of the ratio of renal plasma flows and that there were no major changes in the renal plasma flows of the control kidneys. With the reservation necessary under the circumstances, it would appear that very marked changes in the concentration of the urine occurred when the renal blood flow of the experimental kidney was negligibly reduced.

\section{DISCUSSION}

The experiments which have been described indicate that circumstances associated with constriction of one renal artery cause a rise in the concentration of the urine produced by the affected kidney and that the urine from this kidney may become hypertonic to plasma. Participation of pituitary antidiuretic hormone in the phenomenon can be excluded with reasonable certainty for the following reasons: Normal water diuresis characteristic of the absence of antidiuretic hormone was maintained throughout by the contralateral con-

\footnotetext{
8 It has been reported that when PAH and glucose are contained in the same infusion flask there is a chemical change in the PAH which reduces its renal extraction (16). Through an oversight, in some of the present experiments PAH and glucose were mixed in the same flask. However, falls in PAH clearance were observed when no glucose was administered (Table II) and when the PAH and glucose were administered in separate infusions (Table I).
} 
trol kidney. This maximal water diuresis was indicated by the low concentration of the urine when solute excretion was low and by the high rate of excretion of solute-free water (free water clearance) (3) when solute excretion was high. The possibility that the kidney with constricted renal artery was sensitized to amounts of circulating $\mathrm{ADH}$ insufficient to produce detectable effects on the normal kidney may be excluded since 1 ) the administration of amounts of $\mathrm{ADH}$ inadequate to affect the normal kidney had no effect on the experimental kidney, 2) the infusion of moderate amounts of $\mathrm{ADH}$ produced more change in the concentration of the urine from the control than that from the experimental kidney, and 3) during periods of apparent endogenous $\mathrm{ADH}$ secretion (e.g., the first two periods shown in Figure 6) the effect was similar. From these considerations it may be concluded that ADH is not essential to the production of hypertonic urine. These conclusions are in accord with those of del Greco and de Wardener (8). However, in several of the experiments reported by del Greco and de Wardener the control urine concentrations were relatively high and the free water clearances rather low and in these studies the kidneys were, under the control conditions, unresponsive to the effects of ADH. It is therefore impossible to exclude some participation of the hormone in the changes observed when a balloon was inflated in the aorta. The continued normal function of the control kidney while hypertonic urine was produced by the experimental kidney in the present experiments is fully in accord with their conclusions.

It is the presumption that, in accord with the rationale of the experiments, the effects observed are the result of reduction of glomerular filtration rate and the consequent changes in the distribution of solute and water reabsorption along the length of the nephrons. However, the method used produces effects other than reduction of glomerular filtration and it is necessary to consider whether one of these may be directly involved in the experimental results. The most obvious possibility would be an effect mediated by changes in the renal blood flow. Anoxic impairment of transport by the renal tubules might lead to inability to dilute the urine by a process dependent upon solute extraction. However, under such conditions one would expect the composition of the urine to ap- proach that of glomerular filtrate and the fraction of filtered solute excreted in the urine to increase. The changes observed were in the opposite direction: the fall in urine flow and solute excretion was out of proportion to the reduction in the rate of glomerular filtration, especially so when mannitol was not included. Furthermore, the concentrations of sodium and chloride were generally vanishingly small in the more concentrated urine from the experimental kidney and these are the solutes presumably specifically involved in the dilution process. Impairment of the dilution process alone cannot, of course, account for the production of urine hypertonic to plasma.

Anoxic kidney slices have been found to take up water and swell $(17,18)$. Although the mechanism involved in this phenomenon is disputed and it is uncertain whether it involves the simple uptake of water (17) which might increase the concentration of the surrounding medium, or the uptake of solute and water in the proportions in which they occur in the medium (18) which would not change the osmolality of the latter, for present purposes only the uptake of water alone would be pertinent. Such an uptake of water could, presumably, increase the concentration of fluid in the tubule lumen above that characteristic of the rest of the body. However, the process is self-limited since the cells could take up water only until their contents had been diluted to the same concentration as the general body fluids and plasma. On such a basis it is difficult, if not impossible, to account for the continuous formation of hypertonic urine over long periods (e.g., Table I). Furthermore, one would have to make the highly improbable assumption that the "hypertonic cells" selectively take up water from their luminal surfaces deriving the excess water only from the urine while remaining impermeable on their other surfaces where they are exposed to far larger volumes of fluid of normal composition.

Actually it seems probable that the changes in renal blood flow associated with major alterations in urine concentration were not large enough to produce significant renal anoxia, particularly since plasma flow and filtration rate are known to be markedly increased in the dog under conditions of water loading such as those used in these studies.

It seems reasonable, therefore, to attribute the 
effects of inflation of the renal artery cuff to the reduction of glomerular filtration. Further, the data are in accord with the interpretation that the reduction is due to diminution in the volume filtered in all or very nearly all the nephrons rather than to a selective cessation of filtration in a group of nephrons.' If the latter were the case, it would be necessary to postulate that when a 20 per cent reduction of glomerular filtration leads to production of hypertonic urine, the 20 per cent of nephrons, function of which had been abolished, had been responsible for the output of 80 to 85 per cent of the urine water, almost 99 per cent of the excreted sodium and chloride and, from the results of more recent experiments (21), none of the excreted potassium.

The most important effect of reduced glomerular filtration is probably a reduction in the amount of sodium and chloride reaching and reabsorbed by the distal portions of the nephron. The rapid falling off of sodium and chloride excretion as the filtration rate is reduced is in accord with the view that the reabsorption of these ions becomes essentially complete farther and farther up the tubules. Since only the sodium reabsorbed in the more distal portions of the nephron is involved in the process of urinary dilution (3), a limitation is specifically placed on that part of the sodium and chloride reabsorption which contributes to the formation of solute-free water. In addition, it cannot be assumed that the tubule is, even in the absence of antidiuretic hormone, totally' impermeable to water. Experiments showing that the rate of excretion of solute-free water increases with increasing solute excretion (22) indicate that the diffusion gradient for water has an important effect on the amount of water, initially freed by solute reabsorption, that escapes from the tubule.

\footnotetext{
o Experiments very similar in design but differing in the surgical technique from those reported here have been reported by Leaf, Kerr, Wrong, and Chatillon (19). In their studies the experimental kidney was explanted and the renal artery enclosed in a skin cuff. Marked changes in the rate of glomerular filtration in their experiments were not accompanied by any systematic changes in urine concentration. The results in their experiments and in our own were each so internally consistent that it must be presumed that the difference is attributable to the difference in technique. Dr. Leaf has suggested that the changes of glomerular filtration rate in their experiments most likely were due to cessation of the function of certain groups of nephrons (20).
}

Because of the reduced delivery of sodium and chloride to the diluting segment, less water is freed of solute and because of the small amount of residual solute, an increased fraction of the solutefree water escapes from the tubule lumen. Thus, a greatly reduced volume of fluid including only a minimal amount of solute-free water is delivered to the final segment of the nephron presumed to be responsible for the production of hypertonicity $(3,23)$. Removal of only a small volume of the residual water is then necessary for the elaboration of a urine hypertonic to plasma.

The effect of increased excretion of non-reabsorbable solute (mannitol) can be viewed as twofold : 1) in increasing the amounts of sodium and chloride escaping reabsorption in the upper portions of the nephron $(24,25)$, and 2$)$ in exerting a non-specific osmotic effect opposing the escape of water, initially freed of solute, from the tubule (22).

Although urines considerably more concentrated than plasma were produced in these experiments, the urine osmolality never approached the maximal levels which can be obtained with $\mathrm{ADH}$ at low rates of solute excretion. At the same time, the urine volume was never less than the osmolal clearance by more than a few tenths of a milliliter per minute (i.e., $\mathrm{T}^{\mathrm{c}} \mathrm{H}_{2} \mathrm{O}$ was always less than 0.3 ml. per minute). It is unlikely that these limitations could be due to either a limiting osmotic gradient or to a limited absolute capacity for water transport by the concentrating mechanism. These have been considered to be the important parameters for urinary concentration in the presence of maximally effective amounts of $\mathrm{ADH}$ (3). It seems more probable that the limited effectiveness of the concentrating mechanism is attributable to inefficiency of its operation in the absence of $\mathrm{ADH}$.

The results of these experiments are fully in accord with the view that the sole action of ADH in the kidney is on the permeability of the renal tubule to the movement of water along osmotic gradients. Its role in the production of hypertonic urine can be interpreted as 1) facilitating the diffusion of water out of the tubule as solute is removed in the distal segment, thus assuring the delivery of an essentially isotonic fluid to the concentrating segment, and 2) (assuming the mechanism for producing the final hypertonicity to op- 
erate independently) to increase the accessibility of the concentrating mechanism to the water in the tubule. The results are not easily explained in terms of a urinary dilution mechanism based on secretion of water into the urine.

Whatever the specific chain of events involved in the studies reported here, it is obvious that a number of possibilities other than simple changes in the level of circulating ADH must be considered when changes in urine concentration and in the rate of elimination of water loads are encountered. Changes in the amount of sodium reaching the diluting segment or in the capacity of that segment to reabsorb ions can account for major changes in the rate of excretion of water and even for the production of hypertonic urine.

On the other hand, it cannot be assumed that simple reduction of the rate of glomerular filtration in both kidneys on a chronic basis will necessarily result in the phenomena dealt with in these experiments since the continued presence of a normal kidney in these experiments may, as in the studies of Mueller, Surtshin, Carlin, and White (26), prevent compensatory changes which would restore diuresis to normal levels.

\section{SUM MARY}

In water-loaded dogs compression of one renal artery leads to a rise in the concentration of the urine produced by the affected kidney. It is thus possible for one kidney to produce urine hypertonic to plasma while the other kidney excretes water at a maximal rate. The changes were shown not to be due to sensitization of the experimental kidney to the action of minimal amounts of ADH. The important factor concerned is believed to be the reduction of the rate of glomerular filtration and thus the filtered load of sodium and chloride in each nephron. Since reduced amounts of sodium and chloride reach the segment responsible for dilution of the urine, the extent to which the urine can be diluted by abstraction of these ions is limited. Diffusion of water from the diluted urine through the relatively impermeable tubule results in delivery of a small volume of only slightly diluted urine to the concentrating segment. The concentrating mechanism, operating essentially without dependence on $\mathrm{ADH}$, is able to remove enough water to render the urine hy- pertonic to plasma. The role of $\mathrm{ADH}$ is interpreted as that of increasing the permeability of the diluting and possibly the concentrating segments to the movement of water along osmotic gradients. Factors having to do with the load and disposition of sodium as well as ADH must be considered in the interpretation of changes in urine concentration.

\section{REFERENCES}

1. Ussing, H. H., and Andersen, B., The relation between solvent drag and active transport of ions in Proc. Third Internat. Congress of Biochem., C. Liébecq, Ed. Brussels, 1955, p. 434.

2. Sawyer, W. H., and Schisgall, R. M., Increased permeability of the frog bladder to water in response to dehydration and neurohypophysial extracts. Am. J. Physiol., 1956, 187, 312.

3. Smith, H. W., Renal excretion of sodium and water. Federation Proc., 1952, 11, 701.

4. Shannon, J. A., The control of the renal excretion of water. 1. The effect of variations in the state of hydration on water excretion in dogs with diabetes insipidus. J. Exper. Med., 1942, 76, 371.

5. White, H. L., and Heinbecker, P., Observations on creatinine and urea clearances, on responses to water ingestion, and on concentrating power of kidneys in normal, diabetes insipidus, and hypophysectomized dogs. Am. J. Physiol., 1938, 123, 566.

6. Berliner, R. W., and Orloff, J., Unpublished observations.

7. Bartter, F. C., Personal communication.

8. del Greco, F., and de Wardener, H. E., The effect on urine osmolarity of a transient reduction in glomerular filtration rate and solute output during a 'water' diuresis. J. Physiol., 1956, 131, 307.

9. Barger, A. C., Rudolph, A. M., Rokaw, S. N., and Yates, F. E., Chronic unilateral renal artery catheterization: Differential sodium excretion in normal, unanesthetized dogs, and dogs with congestive heart failure. Federation Proc., 1956, 15, 8.

10. Sellwood, R. V., and Verney, E. B., Phil. Transaction Series B, Royal Society of London, 1955, 238, 361.

11. Walser, M., Davidson, D. G., and Orloff, J., The renal clearance of alkali-stable inulin. J. Clin. Invest., 1955, 34, 1520.

12. Kennedy, T. J., Jr., Hilton, J. G., and Berliner, R. W., Comparison of inulin and creatinine clearance in the normal dog. Am. J. Physiol., 1952, 171, 164.

13. Bratton, A. C., and Marshall, E. K., Jr., A new coupling component for sulfanilamide determination. J. Biol. Chem., 1939, 128, 537.

14. Bowman, R. L., Trantham, H. V., and Caulfield, $P$. A., An instrument and method for rapid, depend- 
able determination of freezing-point depression. J. Lab. \& Clin. Med., 1954, 43, 310.

15. Ladd, M., Liddle, L., and Gagnon, J. A., Renal excretion of inulin, creatinine and ferrocyanide at normal and reduced clearance levels in the dog. Am. J. Physiol., 1956, 184, 505.

16. Baldwin, D. S., Schreiner, G. E., Breed, E. S., Wesson, L. G., Jr., and Maxwell, M. H., Depression of apparent $p$-aminohippurate extraction ratio by glucose. J. Clin. Invest., 1950, 29, 614.

17. Robinson, J. R., Osmoregulation in surviving slices from the kidneys of adult rats. Proc. Roy. Soc., London, s. B., 1950, 137, 378.

18. Leaf, A., On the mechanism of fluid exchange of tissues in vitro. Biochem. J., 1956, 62, 241.

19. Leaf, A., Kerr, W. S., Jr., Wrong, O., and Chatillon, J. Y., Effect of graded compression of the renal artery on water and solute excretion. Am. J. Physiol., 1954, 179, 191.

20. Leaf, A., Personal communication.
21. Davidson, D. G., Levinsky, N., and Berliner, R. W., Effect of changes in glomerular filtration on the rate of potassium excretion. To be published.

22. Orloff, J., and Walser, M., Water and solute excretion in pitressin-resistant diabetes insipidus. Clin. Research Proc., 1956, 4, 136.

23. Rapoport, S., Brodsky, W. A., West, C. D., and Mackler, B., Urinary flow and excretion of solutes during osmotic diuresis in hydropenic man. Am. J. Physiol., 1949, 156, 433.

24. Wesson, L. G., Jr., and Anslow, W. P., Excretion of sodium and water during osmotic diuresis in the dog. Am. J. Physiol., 1948, 153, 465.

25. Mudge, G. H., Foulks, J., and Gilman, A., Effect of urea diuresis on renal excretion of electrolytes. Am. J. Physiol., 1949, 158, 218.

26. Mueller, C. B., Surtshin, A., Carlin, M. R., and White, H. L., Glomerular and tubular influences on sodium and water excretion. Am. J. Physiol., 1951, $165,411$. 